\title{
Glutamate Receptors Mediate Dynamic Regulation of Nitric Oxide Synthase Expression in Cerebellar Granule Cells
}

\author{
Stephan L. Baader and Karl Schilling \\ Department of Anatomy and Cell Biology, University of UIm, D-89069 UIm, Germany
}

Nitric oxide $(\mathrm{NO})$ is a multifaceted messenger molecule believed to be involved in neural plasticity and development. Within the cerebellum, the NO synthesizing enzyme, NO synthase (NOS), is expressed exclusively by granule cells and stellate/basket neurons. In the adult cerebellum, levels of NOS expression can be used to define discrete clusters of granule cell populations. Differential expression of NOS by granule cells temporally coincides with the establishment of afferent innervation of granule cells. In primary cerebellar cultures that comprise a functional network of glutamatergic and GABAergic cerebellar neurons, blockade of electrical activity by tetrodotoxin induced the expression of the neuronal isoform of NOS (nNOS) in granule cells. Conversely, direct depolarization of cultured neurons with $\mathrm{K}^{\prime}$ completely downregulated nNOS expression. Suppression of NMDA receptor- and AMPA receptor-mediated spontaneous synaptic signaling in cultured cells resulted in a drastic upregulation of nNOS expression in granule neurons. In contrast, blockade of $\mathrm{GABA}_{\mathrm{A}}$ receptormediated intercellular communication did not affect nNOS expression by granule cells. Blocking N-, P-, and Q-type voltagedependent $\mathrm{Ca}^{2+}$ channels resulted in a graded upregulation of NOS expression, whereas manipulations of the cAMPdependent signal transduction pathway induced no changes. We conclude that nNOS expression in developing cerebellar granule cells is regulated by excitatory neurotransmission and that calcium is an important signal transduction molecule involved in this regulatory process.

Key words: cerebellum; granule cells; Purkinje cells; mossy fiber; nitric oxide synthase; glutamate; neurotransmission; signal transduction; calcium; voltage-dependent $\mathrm{Ca}^{2+}$ channels
Nitric oxide (NO) is a diffusible free radical that has been recognized as a biological messenger in the vascular, immune, and nervous systems. In the nervous system, NO has been reported to be involved in neurotransmitter release, synaptic plasticity, axonal outgrowth, synaptogenesis, and cell death (for review, see Lowenstein and Snyder, 1992; Dawson and Snyder, 1994; Schuman and Madison, 1994; Garthwaite and Boulton, 1995). These data suggest a significant role for $\mathrm{NO}$ in the sculpting of the nervous system and the maintenance of functional neuronal circuits.

The neuronal isoform of the NO synthesizing enzyme (nNOS) is acutely activated by changes in intracellular $\mathrm{Ca}^{2+}$ levels $\left(\left[\mathrm{Ca}^{2+}\right]_{i}\right)$. In contrast to the immunological isoform of NOS, nNOS is considered a constitutively expressed protein. Yet, a number of results suggest that nNOS expression also may he dynamically regulated. Denervation, axotomy, or ischemia can induce NOS or its histochemical equivalent, reduced nicotinamide-adenine dinucleotide phosphate (NADPH)diaphorase activity, in the peripheral nervous system and CNS (Gunluk et al., 1994; Yu, 1994; Yunker and Galligan, 1994; Zhang et al., 1994). Manipulation of the visual sensory input regulates NADPH-diaphorase activity in the tectum (Williams et al., 1994). There also is evidence indicating that several types of neurons transiently express NOS during development (Bredt and Snyder,

\footnotetext{
Received Sept. 18, 1995; revised Nov. 27, 1995; accepted Nov. 29, 1995.

This work was supported by the Bundesministerium für Bildung, Wissenschaft, Forschung, und Technologie (Grant 0316915A), the Deutsche Forschungsgemeinschaft (Grant Kn 200/4-1, TP6), and the Stiftung zur Förderung der molekularbiologischen Forschung (Ulm). We thank S. Gruchmann for her expert technical assistance. Dr. M. Brich and W. Podschuweit are gratefully acknowledged for their help in computational work and I. Seifert for perfect animal husbandry.

Correspondence should be addressed to Dr. K. Schilling. Department of Anatomy and Cell Biology, University of Ulm, Albert-Einstein-Allee 11, D-89069 Ulm, Germany.

Copyright (C) 1996 Society for Neuroscience $0270-6474 / 96 / 161440-10 \$ 05.00 / 0$
}

1994; Wetts et al., 1995). We recently utilized the cerebellum to characterize the developmental expression of nNOS in a well defined neuronal population, cerebellar granule cells. In the adult cerebellum, granule neurons are heterogeneous with respect to nNOS expression, and groups of nNOS-positive cells are separated by granule cells that do not express this enzyme (Hawkes and Turner, 1994; Schilling et al., 1994). Differential expression of nNOS is established during development concomitantly with the afferent innervation of granule cells. Together, these studies suggest that dynamic changes in the expression of nNOS contribute to the overall signaling capacity of a variety of neuronal phenotypes. What is largely unknown are the cellular and molecular mechanisms that regulate nNOS expression, although at least some of the results quoted point to a role for afferent input.

We sought to directly address the relationship between afferent innervation and nNOS expression in cerebellar granule cells. In vivo, cerebellar granule cells receive synaptic input from two principal sources: GABAergic Golgi cells and mossy fibers (for review, see Ito, 1984). The only established neurotransmitter of the latter is the excitatory amino acid glutamate (Somogyi et al., 1986; Garthwaite and Brodbelt, 1989, 1990; Ji et al., 1991). Accordingly, several subtypes of glutamate and GABA receptors were found to be expressed by granule cells in vivo and in vitro (Kutsuwada et al., 1992; Laurie et al., 1992; Meguro et al., 1992; Silver et al., 1992; Ishii et al., 1993; Tanabe et al., 1993; Grandes et al., 1994). When grown in primary dissociated cultures, cerebellar granule cells form a functional synaptic network together with other cerebellar phenotypes. Many of the morphological and physiological characteristics of native cerebellar development are closely replicated in vitro (Schilling et al., 1991; Baptista et al., 1994). We used this culture paradigni to analyze the expression of nNOS and its regulation by synaptic input. Our results indicate 
that in cerebellar granule cells nNOS expression is dynamically regulated by glutamatergic afferents, and that changes of $\left[\mathrm{Ca}^{2+}\right]_{i}$ appear to be crucial for the cellular processing of extracellular signals impinging on nNOS expression.

\section{MATERIALS AND METHODS}

Cell culture. Primary dissociated cerebellar cultures were established from cerebellar tissue of 16-d-old fetal B6C3F1 mice as described (Schilling et al., 1991). Cells were grown at a density of 200,000 cells $/ \mathrm{cm}^{2}$ in defined medium. After $14 \mathrm{~d}$ in vitro (DIV), cultures were treated for $5 \mathrm{~d}$ with the following agents at the concentrations indicated: $1 \mu \mathrm{m}$ tetrodotoxin (TTX), $10 \mu \mathrm{M}$ 6-cyano-7-nitroquinoxaline-2,3-dione (CNQX), $5 \mu \mathrm{M}$ picrotoxin, $10 \mu \mathrm{M}$ diltiazem, $50 \mu \mathrm{M}$ traus-(1S, 3R)-1-amino-1,3cyclopentanedicarboxylic acid (t-ACPD) (Research Biochemicals, Natick, MA); 0.1-1 mM aminophosphonovalerate (AP-5) (Davies et al., 1981), $50 \mu \mathrm{M}$ NMDA, $50 \mu \mathrm{M}$ AMPA, $50 \mu \mathrm{M}$ kainic acid (Tocris Cookson, Bristol, UK); 50-500 nM $\omega$-agatoxin IVA, $2.5 \mu \mathrm{M} \omega$-conotoxin GIVA (Bachem, Heidelberg, Germany); $30 \mu \mathrm{M}$ glycine, $200 \mu \mathrm{M}$ 3-isobutyl-1methylxanthine (IRMX), $10 \mu \mathrm{m}$ forskolin (Sigma, Deisenhofen, Germany). All other chemicals were from Sigma (Deisenhofen, Germany). Stock solutions $(100 \times)$ were prepared according to the manufacturer's suggestions in either diluted ethanol, alkaline, or distilled water and stored at $-20^{\circ} \mathrm{C}$.

For cAMP response element-binding protein (CREB) phosphorylation analysis, cells were incubated with TTX $3 \mathrm{~d}$ before stimulation with specific agents. They were stimulated for 10 min. After fixation in $4 \%$ buffered $p$-formaldehyde solution, cells were stained for NADPHdiaphorase and phosphorylated CREB (pCREB) as described below.

Histochemistry and immunocytochemistry. Cell cultures were fixed with 4\% $p$-formaldehyde in PBS, $\mathrm{pH} 7.4$, for $30 \mathrm{~min}$ and stained by the NADPH-diaphorase technique and/or immunocytochemistry. NADPHdiaphorase activity was demonstrated by incubating fixed cultures for up to $3 \mathrm{hr}$ with $250 \mu \mathrm{g} / \mathrm{ml}$ nitroblue tetrazolium and $1 \mathrm{mg} / \mathrm{ml} \beta-\mathrm{NADPH}$ dissolved in PBS $/ 0.3 \%$ Triton X-100. Immunocytochemistry was performed as described (Schilling et al., 1991) and the immunoreaction was visualized by the avidin-biotin complex ( $\mathrm{ABC}$ ) tcchnique or immunofluorescence. The following antibodies were used: anti-calbindin D28K (Sigma, Deisenhofen, Germany; clone CL300; dilution 1:4000); antimicrotubule-associated protein (MAP2) (Sigma; clone HM-2; dilution 1:400); anti-neuron-specific enolase (Dako, Hamburg, Germany; dilution 1:5000); anti-pCREB (Biomol, Hamburg, Germany; dilution 1:1500) (Ginty et al., 1993). Anti-synaptophysin was generously provided by Dr. R. Jahn (Yale University, New Haven; dilution 1:500) (Jahn et al., 1985). Anti-GABA was a gift from Dr. C. Matute (University of Leioa Vizcaya Spain; dilution 1:5000) (Matute and Streit, 1986), and the glutamate decarboxylase antiserum GAD 1440-4 was generously provided by Dr. I. J. Kopin (National Institutes of Health, Bethesda, MD; dilution 1:500). Dr. Mayer (University of Graz, Graz, Austria) provided the anti-nNOS antibody (dilution 1:2000) (Klatt et al., 1992).

Microscopy. Culturcs wcre vicwed and photographed using cither a Zeiss Axiophot microscope (Jena, Germany) or a Leitz TLC confocal microscope (Leica, Heidelberg, Germany). In cultures double-labeled for NADPH-diaphorases and synaptophysin, the diaphorase signal was recorded in the reflective mode and combined with the fluorescent synaptophysin image, which was recorded in the extended focus mode.

Western blotting. Immunoblotting was performed essentially as described (Schilling et al., 1989). In brief, primary cerebellar cultures were lysed in SDS-page loading buffer. Proteins were separated on $7.5 \%$ gels, and $15 \mu \mathrm{g}$ total protein were loaded per line. After transfer onto nitrocellulose membranes, blots were stained with antibodies to nNOS and to neuron-specific enolase. The immunoreaction was visualized by the enhanced chemiluminescence system according to the instructions of the supplier (Amersham, Braunschweig, Germany).

Calcium measurements. Relative $\left[\mathrm{Ca}^{2+}\right]_{\mathrm{j}}$ was cvaluatcd by the Fura-2 technique (Connor et al., 1987; Beani et al., 1994) as described in detail by Pressmar et al. (1994). Briefly, cells were loaded with Fura-2 60 min before the start of the experiments by incubation with $2 \mu \mathrm{M}$ Fura-2 AM (Calbiochem, Bad Soden, Germany) diluted in dimethylsulfoxide at $37^{\circ} \mathrm{C}$ in an atmosphere containing $10 \% \mathrm{CO}_{2}$. Cells then were rinsed three times with a solution containing (in $\mathrm{mM}$ ): $130 \mathrm{NaCl}, 5.4 \mathrm{KCl}, 1.8 \mathrm{CaCl}_{2}, 5.5$ glucose, and $20 \mathrm{HEPES}$ adjusted to a $\mathrm{pH}$ of 7.3. Individual cells were selected according to their appearance when viewed by phase-contrast optics, and single cells were measured with a photomultiplier attached to a microscope photometer and adapted for two wavelengths of fluores- cence (PM200, Zeiss, Oberkochen, Germany). All measurements were performed at room temperature. Emission was recorded at 340 and 380 $\mathrm{nm}$, and the ratio of these two values, which is proportional to $\left[\mathrm{Ca}^{2+}\right]_{\mathrm{i}}$, was calculated. For further details, see Pressmar et al. (1994). Pharmacological agents were bath-applied using a micropipette pointed at the cell under investigation. Typically, $\sim 10 \mu \mathrm{l}$ of a solution was applied at the concentration given in Results. All reagents were washed out by five to ten complete changes of the medium.

\section{RESULTS}

\section{Cultured granule cells are integrated in a functional synaptic network}

Primary dissociated cerebellar cultures derived from 16-d-old fetal mice contain glial cells, GABAergic neurons (including Purkinje cells), and NOS-expressing neurons. Glial fibrillary acidic protein (GFAP)-positive glial cells are characterized by a distinct stellate shape (Fig. 1A). GABA immunopositive cells can be differentiated further as NOS-positive hasket and stellate cells, Golgi cells, and the most prominent cerebellar GABAergic cell type, Purkinje cells. Purkinje cell somata typically measure $\sim 25$ $\mu \mathrm{m}$ in diameter; they emanate a single axon and one or more processes that branch extensively and build up a dense dendritic tree (Fig. 1B,C). Purkinje neurons can also be identified by their exclusive expression of calbindin (Fig. 1B,C) and L7/pcp-2 (data not shown) (cf. Oberdick et al., 1988; Schilling et al., 1991). GABAergic neurons other than Purkinje neurons typically have a cell body of $\sim 15-20 \mu \mathrm{m}$ in diameter and several long neurites, which form a dense neuronal network (Fig. 1D). The vast majority of cerebellar cells growing in culture are characterized by a small soma $(<10 \mu \mathrm{m}$ in diameter), a scant cytoplasm, and two to six rather short, unbranched processes (Fig. $1 E$ ). These cells stain blue by the NADPH-diaphorase technique and are classified as granule neurons (Fig. 1A,B,E) (cf. Gao and Hatten, 1994).

After several days in culture, these distinct neuronal phenotypes become integrated into a dense network and form numerous synapses. Immunostaining with antibodies to synaptophysin, a secretory vesicle-associated protein involved in exocytosis, resulted in a punctuate staining (Fig. 1C-E) typical for synapses in vivo and in vitro (Navone et al., 1986; Schilling et al., 1989). To determine whether this synaptic network was indeed active, we took advantage of the fact that synaptic communication activates immediate early genes in postsynaptic cells (Sheng and Greenberg, 1990; Morgan and Curran, 1991; Ghosh and Greenberg, 1995). Cultured cerebellar granule cells grown in standard medium show intense staining for the Ser ${ }^{133}$-phosphorylated CREB protein (data not shown). This staining was abolished in cultures in which electrical activity had been suppressed by TTX (Fig. $1 F$ ). Treatment of TTX-blocked cultures with cxogcnous glutamatc again induced CREB phosphorylation (Fig. 1G).

CREB phosphorylation in glutamate-treated granule cells suggests that they express functional glutamate receptors. To further characterize these receptors, we treated cultured granule cells with specific glutamatergic agonists and antagonists, and monitored their response by measuring changes in $\left[\mathrm{Ca}^{2+}\right]_{i}$ using the Fura-2 technique (Connor et al., 1987). For each agonist and antagonist or combinations thereof, $\sim 10$ granule cells, selected randomly from several cultures, were analyzed. Application of NMDA alone did not result in a detectable change of $\left[\mathrm{Ca}^{2+}\right]_{\mathrm{i}}$. However, the addition of glycine, known to potentiate NMDAevoked elevation of $\left[\mathrm{Ca}^{2+}\right]_{i}$ (Simpson et al., 1994), induced a clearly detectable increase in $\left[\mathrm{Ca}^{2+}\right]_{\mathrm{i}}$ (Fig. $2 A$ ). This increase was completely blocked by the NMDA receptor antagonist AP-5. The AP-5 block was reversible, and after washout of AP-5, the same 

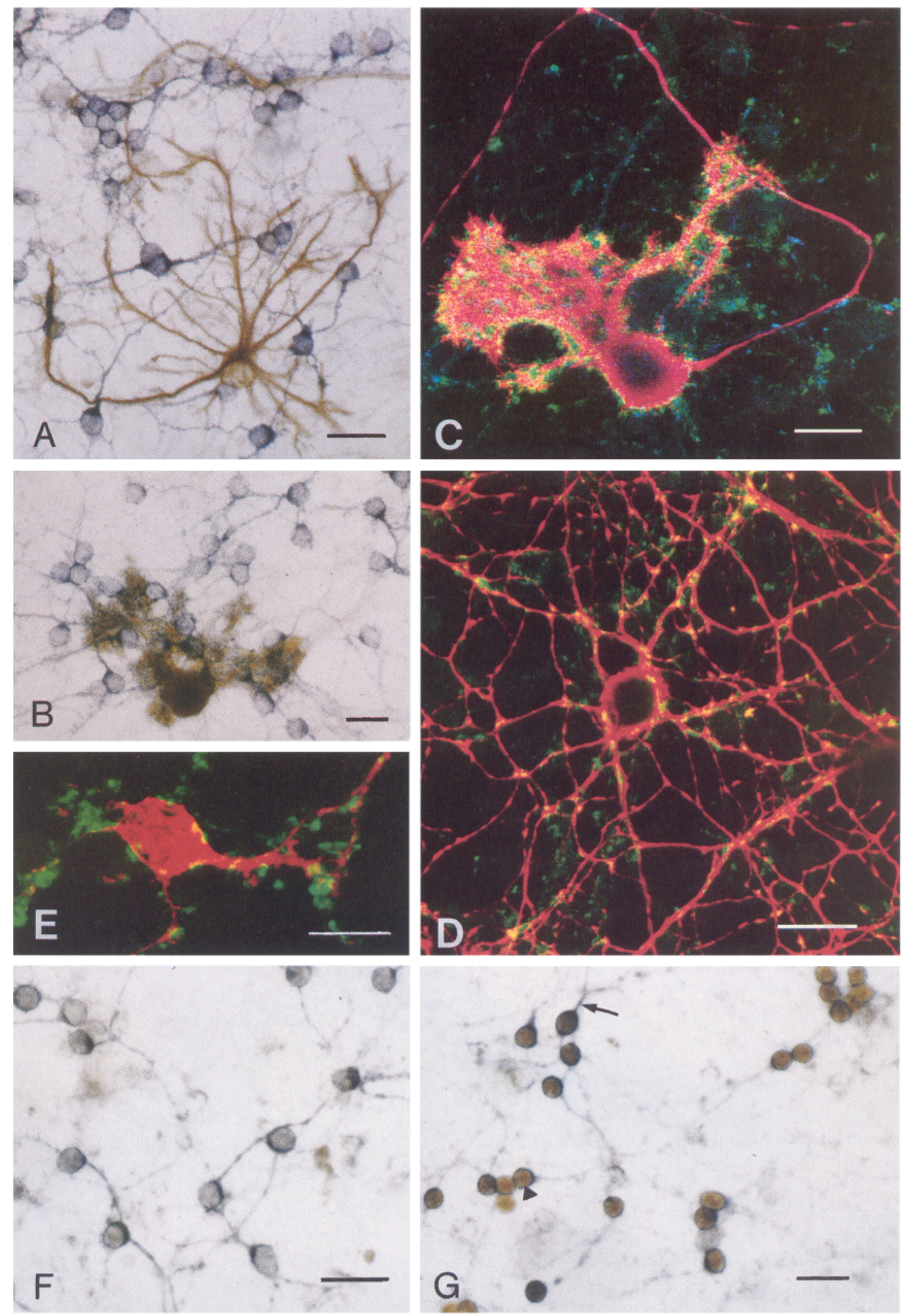

Figure 1. Cellular composition of primary dissociated cerebellar cultures grown for $14 \mathrm{~d}$ in vitro. A, Immunolabeling for GFAP and histochemical staining for NADPH-diaphorase reveals the presence of astroglia (brown) and the characteristic morphology of NOS-positive granule cells (blue). This culture had been treated with TTX for $5 \mathrm{~d}$ before staining. Scale bar, $20 \mu \mathrm{m}$. B, Double labeling for calbindin D28K (brown) and NADPH-diaphorase (blue) shows the typical morphology of cultured Purkinje and granule cells and reveals the topographic relationship of these two cell types in culture. The dendritic tree of the Purkinje cell is covered by numerous diaphorase-positive dots. Scale bar, $20 \mu \mathrm{m}$. $C$, Triple labeling for calbindin D28K (red), synaptophysin (green), and the GABA-synthesizing enzyme glutamic acid decarboxylase (GAD; blue). The GAD antiserum used recognizes both the 65 and $67 \mathrm{kDa}$ 

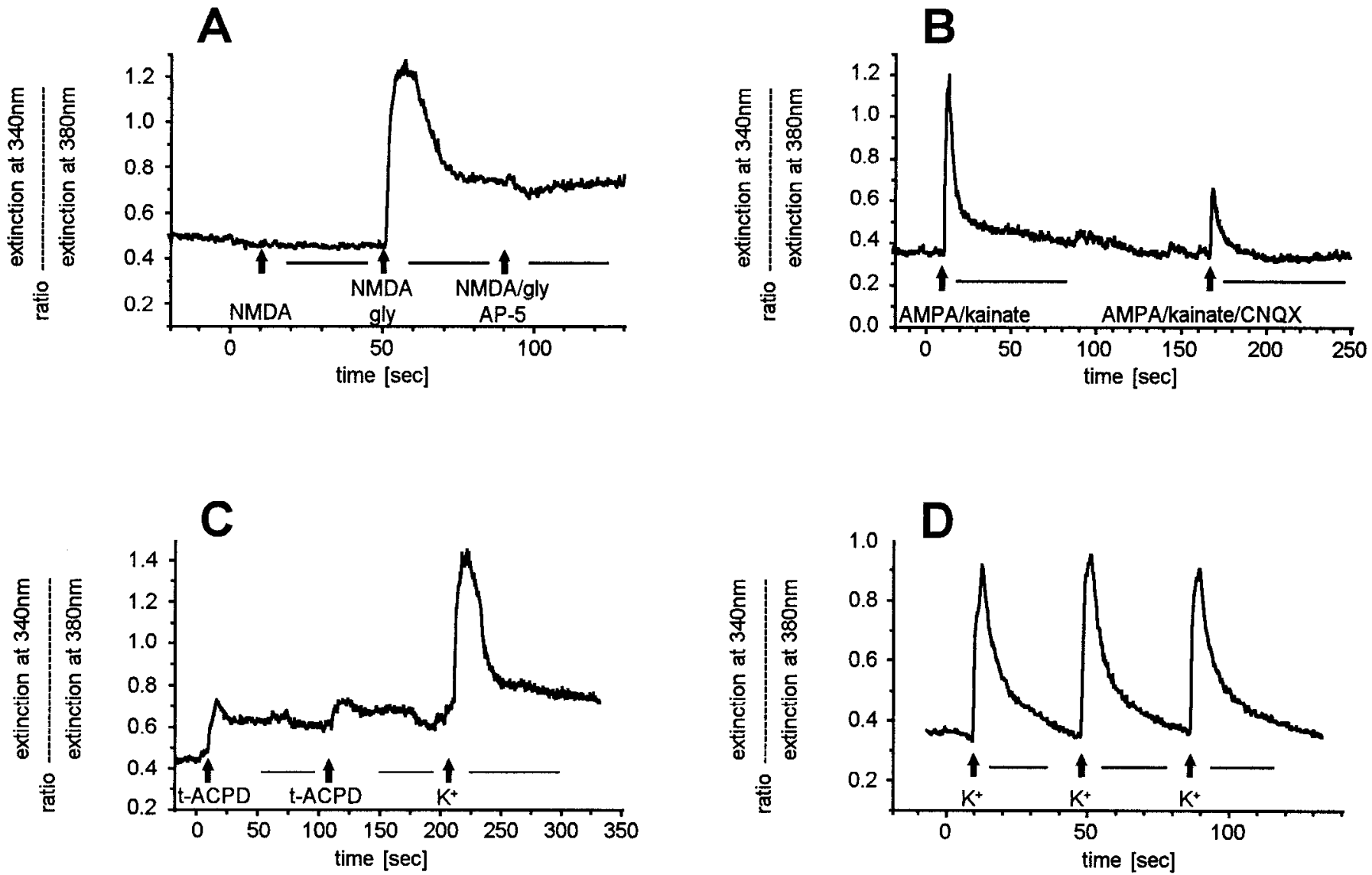

Figure 2. Changes in $\left[\mathrm{Ca}^{2+}\right]_{\mathrm{i}}$ in cerebellar granule cells either stimulated with glutamatergic agonists or directly depolarized with $\mathrm{K}^{+}$. Vertical arrows indicate time points of agent applications, and horizontal bars mark wash periods. $A$, The NMDA $(50 \mu \mathrm{M})$-induced increase in $\left[\mathrm{Ca}^{2+}\right]_{\mathrm{i}}$ in the presence of $3 \mu \mathrm{M}$ glycine $(g / y)$ was blocked by the specific NMDA receptor antagonist AP-5 (1 mM). $B$, The Ca ${ }^{2+}$ increase evoked by a combination of AMPA (50 $\mu \mathrm{M})$ and kainate $(50 \mu \mathrm{M})$ is largely blocked by CNQX $(10 \mu \mathrm{M})$, a specific antagonist of the non-NMDA family of ionotropic glutamate receptors. $C$, The metabotropic agonist t-ACPD $(50 \mu \mathrm{M})$ induces a moderate increase in $\left[\mathrm{Ca}^{2+}\right]_{i}$. Subsequent direct depolarization of the same cell results in a robust and transient signal, attesting to the functional competence of the cell tested. $D$, Elevations of $\left[\mathrm{Ca}^{2+}\right]_{i}$ were obtained after repetitive direct membrane depolarization with $\mathrm{K}^{+}(30 \mathrm{~mm})$. Changes in $\left[\mathrm{Ca}^{2+}\right]_{i}$ are proportional to shifts in the ratio of the extinctions obtained from unbound Fura- 2 versus $\mathrm{Ca}^{2+}$-bound Fura-2.

cell could again be stimulated with NMDA. Analogous results were obtained when a combination of AMPA and kainate, nonNMDA receptor agonists, and CNQX, a non-NMDA receptor specific antagonist, were used. AMPA/kainate induced a sleep increase in $\left[\mathrm{Ca}^{2+}\right]_{\mathrm{i}}$, which could be blocked by CNQX (Fig. $2 B$ ). After washout of CNQX, the cells again became sensitive to the non-NMDA receptor agonist mixture. Stimulation of granule cells with the metabotropic glutamate analog $\mathrm{t}-\mathrm{ACPD}$ resulted in a moderate, but reproducible increase in the levels of $\left[\mathrm{Ca}^{2+}\right]_{i}$. We used direct depolarization of the very same cells stimulated with t-ACPD to verify that the cells were indeed capable of generating a robust calcium signal when appropriately activated (Fig. $2 C$ ).

\section{nNOS expression in cerebellar cultures}

The NADPH-diaphorase staining technique is an established histochemical method to specifically detect NOS within the central nervous system, including the cerebellum (Dawson et al., 1991; Matsumoto et al., 1993; Schilling et al., 1994). Throughout the

isoforms of the enzyme, which is specifically expressed by GABAergic cells and their processes. The red/purple staining of the Purkinje cell is attributable to colocalization of calbindin and GAD to the Purkinje cell. Numerous synaptophysin-positive dots outline both the dendritic tree and the cell body of the Purkinje neuron. These represent synapses (see Results). The yellow staining is attributable to the very close apposition of synaptophysin-containing nerve terminals to calbindin-positive postsynaptic dendrites, which, at the resolution used, gives the impression of "colocalization." Scale bar, $20 \mu \mathrm{m} . \mathrm{D}$, Immunostaining for GABA (red) reveals that GABAergic cells have formed a dense neuritic network. A typical GABAergic cell body is shown in the middle of the figure. Counterstaining for synaptophysin (green) demonstrates the presence of numerous GABA-negative terminals. Yellow may indicate the true colocalization of synaptophysin and GABA within GABAergic cells or a very close apposition between GABAergic cells and synaptophysinpositive structures beyond the limit of optical resolution used here. Scale bar, $20 \mu \mathrm{m}$. $E$, Double labeling for NADPH-diaphorase (red) and synaptophysin (green). Note the close apposition of numerous synaptophysin-positive dots and clusters along the processes of the diaphorase-labeled granule neuron. Scale bar, $10 \mu \mathrm{m} . F$ and $G$, Glutamate-induced phosphorylation of CREB in granule cells. Before staining, cultures were treated with TTX for 5 d both to enhance NOS expression and to suppress CREB phosphorylation resulting from spontaneous electrical activity. Under these conditions $(F)$, diaphorase-positive (blue) granule cells did not stain for pCREB. After stimulation with glutamate $(G)$, intense immunostaining for pCREB (brown) can be seen in granule cell nuclei (arrowhead). The surrounding cytoplasm and the neurites (arrow) are stained blue using the diaphorase assay. Scale bar, $20 \mu \mathrm{m}$. 


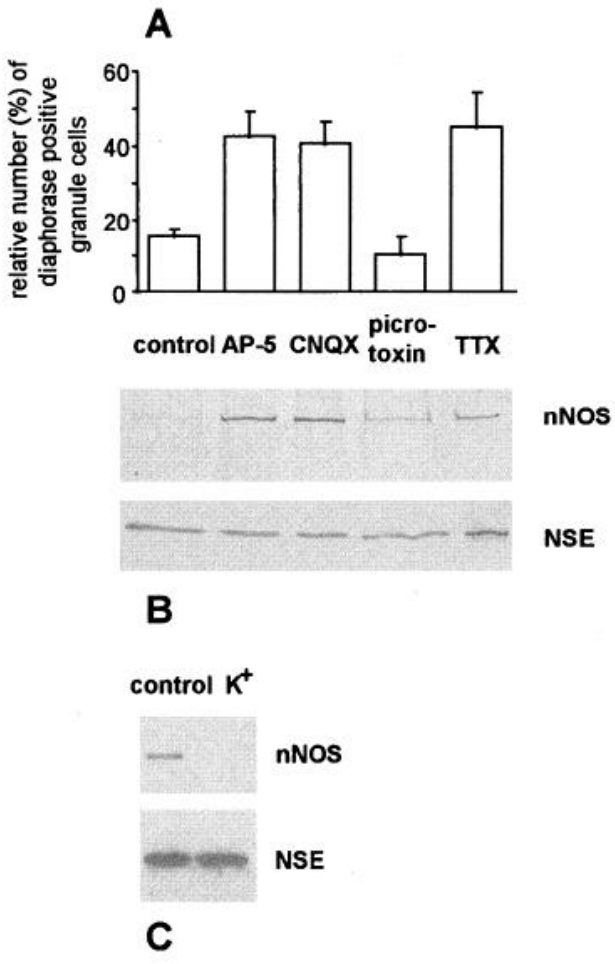

Figure 3. Quantification of nNOS in primary dissociated cerebellar cultures. $A$, Numbers of NADPH-diaphorase-positive granule cells were counted and related to the total number of granule cells. NADPHdiaphorase-negative granule cells were identified by their typical morphology when viewed in phase-contrast optics. For each treatment, four to seven independent cultures were evaluated, and at least 100 cells were counted per culture. Values represent mean \pm SEM. There is a clear-cut and statistically significant $(p<0.05$; ANOVA and Tukey-Kramer test) increase in the numbers of NADPH-diaphorase-positive cells after treatment with $A P-5(1 \mathrm{mM}), C N Q X(10 \mu \mathrm{M})$, or $T T X(1 \mu \mathrm{M})$. Picrotoxin (picrotoxin; $5 \mu \mathrm{M}$ ) did not increase the numbers of NADPH-diaphorasestained cells. No attempt was made to classify NADPH-diaphorasepositive cells according to their staining intensity, although it was obvious that the average staining of granule cells in cultures treated with AP-5, CNQX, or TTX was much more intense than that of controls. $B$, Evaluation of $n N O S$ levels in primary cultures by immunoblotting. (Top panel, left) In control cultures, only a very faint band with the appropriate molecular weight for nNOS is labeled by the specific antibody. This band is much more intense in cultures treated with AP-5, CNQX, or TTX $5 \mathrm{~d}$ before analysis. Repeated experiments established that the weak band seen in the lane containing proteins from a picrotoxin-treated culture is not much different in intensity from that seen in controls. The bottom panel shows the part of the same blot containing neuron-specific enolase (NSE), and the equal staining seen in all cultures attests to the specificity of the effects seen on nNOS. $C$, A heavily overloaded blot demonstrates the downregulation of nNOS after chronic depolarization of cultures with $\mathrm{K}^{+}$.

culture period of 3 weeks, nNOS is expressed at low levels such that only a few cells with a faint, but unambiguous blue staining could be detected. Blockade of electrical activity in 14-d-old cultures by treating neurons with TTX upregulates diaphorasestaining intensity (Fig. 3A) (see also Schilling et al., 1994), resulting in the staining of many more neurons with the typical morphology of granule cells. To assess NOS expression in differentially treated cerebellar cultures, we counted NADPHdiaphorase-positive cells and related them to the numbers of unstained granule cells characterized by their typical morphology. Although this approach cannot account for the NOS concentration in individual cells, which is reflected in the staining intensity, we expect that the relative numbers of NOS-positive granule cells provide a semiquantitative measure of NOS expression in culture. To further pursue this notion, we measured NOS expression in control and TTX-treated cultures by immunoblotting. As shown in Figure $3 B$, the NOS signal in the lane containing proteins of a culture grown under standard conditions is very weak compared with the signal obtained from TTX-treated cells. The equal intensities of the neuron-specific enolase signal seen with both cultures demonstrates the equal loading efficiency and attests to the specificity of the effect. Thus, immunoblotting concurs with the cell count approach to demonstrate a strong and specific upregulation of nNOS expression after blockade of electrical activity. The effect of TTX treatment was dependent on the age of the cultures. In cultures older than $7 \mathrm{~d}$, a 2.5-d-long incubation in TTX resulted in a robust and reproducible increase in the numbers and staining intensity of nNOS-expressing granule cells. In contrast, treatment of cultures younger than $5 \mathrm{~d}$ with TTX did not appreciably affect NADPH-diaphorase staining intensity or numbers of granule cells.

Conversely to blockade of electrical activity, chronic activation of cultured cerebellar neurons, achieved by growing them in medium containing a depolarizing concentration of $\mathrm{K}^{+}$, resulted in a complete loss of NADPH-diaphorase staining. In Western blots prepared from $\mathrm{K}^{+}$-treated cultures, we could not detect any nNOS signal. That was also true when the blots were heavily overloaded, such as to maximize the chance to detect small quantities of nNOS (Fig. $3 C$ ). This loss of nNOS was not because of granule cell death. As verified by immunostaining for MAP-2, $\mathrm{K}^{+}$-treated cultures contained an equally dense complement of neurons as cultures grown under standard conditions; furthermore, we could not detect any obvious morphological differences between the neurons growing under standard conditions and those treated with $\mathrm{K}^{+}$for $5 \mathrm{~d}$. Finally, after downregulation by $\mathrm{K}^{+}$, nNOS could be reinduced in granule cells by changing the medium and treating the cultures with TTX. Together, these results suggest an activity-dependent regulation of nNOS expression in cultured cerebellar granule cells.

To evaluate which transmitter(s) are involved in this dynamic regulation of nNOS expression, we chronically eliminated glutamatergic or GABAergic transmission between cultured neurons using appropriate pharmacological agents. All treatments were started on DIV 14 and maintained for $5 \mathrm{~d}$. Inhibition of glutamatergic transmission with both the specific NMDA receptor antagonist AP-5 (1 mM) and the non-NMDA antagonist CNQX (10 $\mu \mathrm{M}$ ) drastically upregulates nNOS expression (Fig. $3 A, B$ ). This is obvious from the analysis of histochemically stained preparations (Fig. $3 A$ ) and is confirmed by immunoblotting (Fig. $3 B$ ). Significantly increased levels of NOS expression can also be obtained in cultures treated with $100 \mu \mathrm{M}$ AP-5, although under these conditions, the increase is less than after treatment with $1 \mathrm{~mm} \mathrm{AP-5.}$ This may be because of the stability of AP-5 under our culture conditions. The $\mathrm{K}^{+}$-induced downregulation of nNOS expression cannot be prevented by the simultaneous treatment with the ionotropic glutamate receptor antagonists AP-5 and CNQX (Fig. $4 B$ ).

GABAergic neurotransmission mediated by $\mathrm{GABA}_{\mathrm{A}}$ receptors can be blocked by picrotoxin. When cultures were treated with 5 $\mu \mathrm{M}$ picrotoxin, no appreciable changes of NOS levels, as assessed by counting of NADPH-diaphorase-positive cells or by immunoblotting, were observed (Fig. $3 A, B$ ). The faint NOS signal visible after treatment with picrotoxin in Figure 3 was within the range of control values obtained in repeated experiments, and it was 

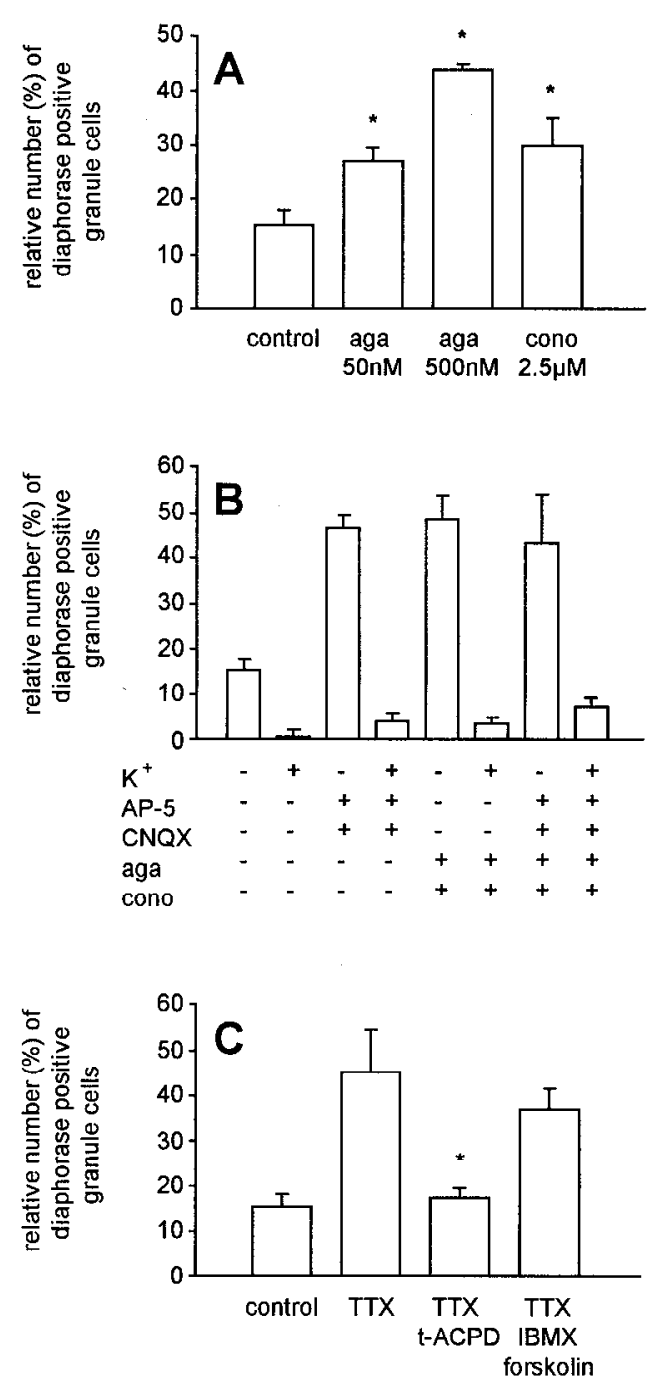

Figure 4. nNOS expression in cultured granule neurons after manipulation of various signal transduction pathways. nNOS expression was evaluated by counting numbers of NADPH-diaphorase-positive granule cells and relating them to total numbers of granule cells in culture. No attempt was made to classify NADPH-diaphorase-positive cells according to their staining intensity, but it was obvious that the average staining of granule cells in cultures correlated positively with numbers of diaphorase-stained cells. Changes in NOS expression were evaluated in cultures derived from at least three independent experiments and statistically analyzed using one-way ANOVA followed by post hoc Tukey-Kramer test. $A$, Blockade of P-type VDCCs with $50 \mathrm{~nm} \omega$-agatoxin IVA (aga), P- and Q-type channels with $500 \mathrm{nM} \omega$-agatoxin IVA (aga), and N-type channels with 2.5 $\mu \mathrm{M} \omega$-conotoxin GIVA (cono) all resulted in a clear-cut increase in numbers of diaphorase-stained granule cells. Statistical significance (*) was established at $p<0.05$ for control versus aga (50 nM), control versus aga $(500 \mathrm{nM})$, control versus cono $(2.5 \mu \mathrm{M})$, and aga $(50 \mathrm{nM})$ versus aga $(500 \mathrm{nM}) . B$, Chronic (5 d) depolarization with $30 \mathrm{~mm} K^{+}$reduced the numbers of diaphorase-stained granule cells to nearly undetectable levels. This effect was not counteracted by blockade of ionotropic glutamate receptors with $A P-5$ and $C N Q X$ or by blockade of voltage-dependent $\mathrm{Ca}^{2+}$ channels with $\omega$-agatoxin (aga) and $\omega$-conotoxin (cono), or the combination of these blockers. Note that all blockers effectively upregulated numbers of nNOS-expressing cells in cultures grown in normal medium. $C$, Pharmacological stimulation of metabotropic glutamate receptors with t-ACPD $(50 \mu \mathrm{M})$ abrogated the $T T X$ induced increase in numbers of NADPH-diaphorase-positive granule cells $(*)(p<0.01$; ANOVA and Tukey-Kramer test). Direct activation of adenylate cyclase with $200 \mu \mathrm{M}$ forskolin and concomitant inhibition of phosphodiesterases with $10 \mu \mathrm{M}$ $I B M X$ did not change the TTX-induced increase in diaphorase-positive cells. clearly less than the strong signal seen in probes prepared from TTX-, NMDA-, or CNQX-treated cultures. To evaluate whether the lack of effect of $\mathrm{GABA}_{\mathrm{A}}$ receptor blockade was attributable to an adverse effect of picrotoxin on granule cell viability, we monitored the numbers and morphology of neurons in picrotoxintreated cultures after immunostaining for MAP-2. We could not detect any difference, either in the overall neuronal density or in the morphology of cultured neurons that stained for MAP-2 between control and picrotoxin-treated cultures. To further test the viability of picrotoxin-treated granule cells, we switched picrotoxin-treated cultures to a medium containing $1 \mu \mathrm{M}$ TTX for an additional $5 \mathrm{~d}$. This ensued an upregulation of nNOS expression and a clear-cut staining of numerous nNOS-positive granule cells.

Together, these data suggest a role for glutamatergic neurotransmission in the transsynaptic regulation of nNOS expression; GABAergic neurotransmission does not appear to have an effect on nNOS expression in cultured cerebellar granule cells.

\section{Role of calcium as a mediator of glutamate-regulated NOS expression}

Two major consequences of the activation of AMPA and NMDA receptors are depolarization of the cell membrane and changes in $\left[\mathrm{Ca}^{2+}\right]_{i}$. The NMDA receptor forms a $\mathrm{Ca}^{2+}$ permeant channel. Most AMPA receptors, in contrast, display only a very low permeability for calcium. However, AMPA receptor-mediated depolarization of the cell membrane activates voltage-dependent $\mathrm{Ca}^{2+}$ channels (VDCC). Thus, both glutamate receptors are expected to either directly or indirectly increase $\left[\mathrm{Ca}^{2+}\right\rfloor_{\mathrm{i}}$, and they do so in cultured granule cells (Fig. $2 A, B$ ). Similar to glutamatergic stimulation, direct depolarization with $\mathrm{K}^{+}$also increases $\left[\mathrm{Ca}^{2+}\right]_{\mathbf{i}}$ in cultured granule cells (Fig. 2D). Indeed, a common aspect of glutamate receptor activation and direct $\mathrm{K}^{+}$-induced depolarization is the activation of VDCC.

We therefore evaluated the effect of chronic blockade of VDCCs on nNOS expression in cultured cerebellar granule cells. To this end, 14-d-old cultures were treated for $5 \mathrm{~d}$ with established pharmacological blockers of $\mathrm{Ca}^{2+}$ channels. Diltiazem $(10 \mu \mathrm{M})$ was used to block L-type VDCCs, and $\omega$-conotoxin GIVA (2.5 $\mu \mathrm{M})$ was used to block N-type VDCCs. A low concentration of $\omega$-agatoxin IVA (50 nM) was used to block P-type VDCCs, and a high concentration of $\omega$-agatoxin IVA ( $500 \mathrm{nM}$ ) was used to block the Q-type channel (Zhang et al., 1993; Olivera et al., 1994; Wheeler et al., 1994).

I'reatment with diltiazem had no obvious effect on the numbers of nNOS-expressing granule cells. In contrast, both $\omega$-agatoxin $(50$ nM) and $\omega$-conotoxin increased the numbers of clearly nNOSpositive cells. Five hundred nanomolars $\omega$-agatoxin were more efficient in increasing numbers of NOS-positive cells than treatment with $50 \mathrm{~nm}$ (Fig. $4 A$ ). These results were obtained with cultures grown under standard culture conditions. The simultaneous treatment of cultures with high levels of $\mathrm{K}^{+}$and $\omega$-agatoxin IVA, $\omega$-conotoxin GIVA, or a combination of these two blockers for 5 d failed to suppress the $\mathbf{K}^{+}$-induced downiregulation of nNOS (Fig. 4B). Similarly, further addition of AP-5 and CNQX also failed to prevent nNOS downregulation under these conditions (Fig. $4 B$ ). We verified that granule cells indeed survived all of these treatment protocols by checking whether they could be induced to reexpress nNOS after treatment with TTX.

Blockade of defined voltage-dependent $\mathrm{Ca}^{2+}$ channels therefore induces the expression of nNOS in cultured granule cells. The tested inhibitors, however, are ineffective in reversing the negative 
effect of $\mathrm{K}^{+}$-induced depolarization on the expression of $\mathrm{nNOS}$ in cerebellar granule cells.

Finally, we also tested the effects of manipulation of GABA receptors on $\left[\mathrm{Ca}^{2+}\right]_{\mathrm{i}}$. In granule cells cultured for $10 \mathrm{~d}$ or more, GABA did not appreciably change levels of free $\mathrm{Ca}^{2+}(340 / 380$ $\mathrm{nm}$ extinction ratio $0.431 \perp 0.098$ vs $0.401 \perp 0.108$ in control cells; Student's $t$ test, $p=0.43 ; n=15$ ). Treatment with $5 \mu \mathrm{M}$ picrotoxin resulted in a moderate and quite variable rise in $\mathrm{Ca}^{2+}$ levels in 13 of 30 cells tested $(340 / 380 \mathrm{~nm}$ extinction ratio $0.695 \pm 0.411$ vs $0.316 \pm 0.093$ in control cells; Student's $t$ test, $p<0.05)$.

\section{Influence of other signal transduction pathways}

Besides ionotropic receptors for glutamate and GABA, a number of reports have described the existence of several other transmitter systems involved in granule cell communication (Connor et al., 1987; Courtney et al., 1990). However, the physiological significance of these systems is far less understood than that of GABA and glutamate. As mentioned above and also shown experimentally, cultured granule cells, like their in vivo counterparts, do cxpress metabotropic glutamate receptors. Upon activation with $\mathrm{t}-\mathrm{ACPD}$, these receptors mediate increases in $\left[\mathrm{Ca}^{2+}\right]_{\mathrm{i}}$ (Fig. $2 \mathrm{C}$ ) either by opening intracellular $\mathrm{Ca}^{2+}$ stores or by activating VDCCs (Sugiyama et al., 1987; Tanabe et al., 1993; Chavis et al., 1995; Pin and Duvoisin, 1995). We could not detect any effect of t-ACPD on nNOS expression when normally active cultures were treated with this agent; however, t-ACPD inhibited the TTXinduced upregulation of nNOS expression (Fig. 4C). This concurs with t-ACPD-induced CREB phosphorylation seen under these conditions (data not shown).

Besides $\mathrm{Ca}^{2+}$, cAMP is a major intracellular second messenger, and several of the transmitters or receptors that putatively act in the cerebellum have been shown to use this signal transduction pathway outside the cerebellum. To screen for a potential effect of the activation of CAMP-mediated signal transduction on nNOS expression, we incubated cultured cerebellar cells with $10 \mu \mathrm{M}$ forskolin and $200 \mu \mathrm{M}$ IBMX. There were no appreciable changes in the expression of nNOS seen after this treatment, neither in cultures grown under control conditions nor in synaptically isolated cultures grown in the presence of TTX (Fig. 4C).

\section{DISCUSSION}

This article presents evidence that expression of nNOS in cerebellar granule cells can be dynamically regulated by manipulating the synaptic input of these neurons. Glutamate, acting through several pharmacologically distinct receptors, provides a major component of this regulation, and $\left[\mathrm{Ca}^{2+}\right]_{i}$ correlates with changes in the expression of nNOS.

The culture paradigm used to analyze nNOS expression shares many of the characteristics of the cerebellum in vivo. It contains all of the major cellular phenotypes of the cerebellum, including glial cells, Purkinje neurons, and granule cells. One qualification is that we could not further differentiate the GABAergic neurons (other than Purkinje neurons) present in culture. These might include Golgi neurons, basket/stellate cells, or deep nuclear neurons, which are also contained in our preparation. Yet there are also significant differences hetween the in vivo and the in vitro situation. Importantly, cultured cerebellar neurons are deprived of all extracerebellar afferents; granule cells in particular do not receive mossy fiber input. Nevertheless, granule cells become integrated into a functional network. Previous analysis of the culture paradigm used here has established that the neuronal network formed in vitro shows spontaneous activity and that both glutamatergic and GABAergic inputs impinge on Purkinje neurons (Schilling et al., 1991). We now show that elevated levels of CREB phosphorylation is one of the consequences of this spontaneous activity, and we utilized this fact to demonstrate that cultured granule cells do in fact express glutamate receptors and receive glutamatergic input. The most likely sources of this input are granule cells themselves. To further characterize the corresponding receptors, we used the Fura- 2 technique to record the $\mathrm{Ca}^{2+}$ response of granule cells to specific glutamatergic agonists and antagonists. The setup used for these experiments allowed only for a relatively slow application and washout of pharmacological agents. This puts some qualification on the time course of changes in $\mathrm{Ca}^{2+}$ levels reported. Nevertheless, our data allow us to conclude that granule cells developing in the culture paradigm used here express functional ionotropic glutamate receptors of the NMDA as well as the non-NMDA class; they also express metabotropic glutamate receptors which, upon activation, increase $\left[\mathrm{Ca}^{2+}\right]_{i}$. Thus, cultured granule cells are furnished with a qualitatively comparable complement of glutamate receptors as granule cells in vivo (Kutsuwada et al., 1992; Meguro et al., 1992; Silver et al., 1992; Ishii et al., 1993; Farrant et al., 1994; Grandes et al., 1994). Cultured cerebellar granule cells also have been shown to express GABA A receptors (Gao and Fritschy, 1995), and GABA-mediated synaptic signaling has heen shown to occur in the culture paradigm used here (Schilling et al., 1991).

A distinct advantage of cultured neurons over their in vivo counterparts is that their environment and intercellular communication are readily accessible to experimental manipulation. Blockade of $\mathrm{GABA}_{\mathrm{A}}$ receptor-mediated intercellular signaling did not appreciably affect nNOS expression. This concurs with the observation that GABA receptor stimulation does not affect $\left[\mathrm{Ca}^{2+}\right]_{\mathrm{i}}$ in cultures older than $10 \mathrm{~d}$, and that blockade of $\mathrm{GABA}_{\mathrm{A}}$ receptors in these cultures results in only a slight and somewhat variable increase in $\left[\mathrm{Ca}^{2+}\right]_{\mathrm{i}}$, which seems to be pivotal in transducing the effect of glutamate on nNOS expression (see below). Moreover, this latter effect is seen only in a subgroup of cultured neurons. Thus, in the network formed in vitro, GABAergic inhibition of glutamatergic granule cells seems to be of minor significance for the regulation of perikaryal levels of free $\mathrm{Ca}^{2+}$ and its downstream consequences. The details underlying this observation, e.g., the relative prevalence of GABAergic and glutamatergic synapses, their exact positioning on cultured granule cells, or the precise nature of the channels involved, are currently not known. However, this finding is reminiscent of observations made on acutely isolated cerebellar Purkinje neurons, which show that GABA only marginally affects glutamate receptor-mediated $\mathrm{Ca}^{2+}$ influx (Sorimachi et al., 1991). In contrast to $\mathrm{GABA}_{\mathrm{A}}$ receptor blockade, chronic blockade of electrical activity with TTX, and specifically of NMDA or non-NMDA receptors in cultured granule cells, resulted in a drastic upregulation of nNOS expression. These changes in nNOS expression were documented quantitatively by immunoblotting and by a clear-cut increase in NADPHdiaphorase staining intensity on the single-cell level. The age dependence of the effect of TTX on nNOS expression correlated with the emergence of electrical/synaptic activity in these cultures reported previously (Schilling et al., 1991).

The notorious toxic effects of glutamate, NMDA, or AMPA (Meldrum and Garthwaite, 1990; Lafon-Cazal et al., 1993; Brorson et al., 1995) precluded the analysis of the consequences of direct activation of their receptors. Prolonged application of these agents in levels equivalent to glutamate concentrations reached in the synaptic cleft (Clements et al., 1992) resulted in generalized 
neuronal death (data not shown). To circumvent this problem, we resorted to indirect stimulation of endogenous glutamatergic transmission by exposing the cultures to depolarizing concentrations of $\mathrm{K}^{+}$. Originally, this series of experiments was planned under the assumption that any stimulation of overall network activity should enllance glutamatergic transmission, and that the concomitant decrease in nNOS expression should be preventable by blockade of NMDA and non-NMDA ionotropic receptors. Although depolarization effectively downregulated nNOS levels, this effect could not be precluded by blockade of ionotropic glutamate receptors. This indicates that $\mathbf{K}^{+}$-induced membrane depolarization activates the signal transduction cascade impinging on nNOS expression downstream of ionotropic glutamate receptors.

Both activation of ionotropic glutamate receptors and pharmacological membrane depolarization cause an increase in $\left[\mathrm{Ca}^{2+}\right]_{i}$, either by direct permeation of glutamate receptors (preferentially of the NMDA type) (Yuste and Katz, 1991) or by the activation of VDCC. We therefore determined the effect(s) of VDCC blockade on levels of nNOS in cerebellar cultures grown under standard conditions. Blockade of N-, P-, and Q-type VDCCs resulted in a clear-cut and reproducible upregulation of nNOS expression as judged by the numbers and staining intensity of NADPHdiaphorase-positive granule cells. Although independent blockade of the P- and Q-type channels is not feasible with the agents used, a role for Q-type channels may be inferred from the fact that high concentrations $(500 \mathrm{~nm})$ increased the numbers of NADPHdiaphorase-positive cells beyond that seen after treatment with 50 nM. The latter concentration has been shown to block P-type, but not Q-type VDCCs (Olivera et al., 1994). None of the $\mathrm{Ca}^{2+}$ antagonists used, or combinations thereof, was sufficient to prevent depolarization-induced $\mathrm{Ca}^{2+}$ influx (data not shown) and nNOS downregulation. This is consistent with the notion that granule cells express additional VDCCs, which are not blocked by the agents used. Indeed, granule cells have been shown to be endowed with a number of diverse VDCCs for which we still lack specific blockers (Forti et al., 1994; Randall and Tsien, 1995). The cellular heterogeneity and the limited number of granule cells that can be obtained in primary culture suggest that the intracellular mechanisms that regulate nNOS mRNA abundance and utilization might be better analyzed in a more reductionistic model, such as permanent cell lines. The results reported here establish one defined extracellular signal impinging on such mechanism(s) and help to formulate testable hypotheses for further experimentation.

From the present results, two conclusions may be made. First, these experiments establish a role for VDCCs in the regulation of nNOS expression. Second, they suggest that the regulation of nNOS levels via $\mathrm{Ca}^{2+}$ is promiscuous with respect to the pathway that brings about changes in $\left[\mathrm{Ca}^{2+}\right]_{\mathrm{i}}$. This point is further supported by the observation that activation of metabotropic glutamate receptors, thought to mediate increases in $\left[\mathrm{Ca}^{2+}\right]_{i}$ by opening intracellular stores and/or modulation of VDCCs (Tanabe et al., 1993), can also downregulate the levels of nNOS in granule neurons.

Thus, it appears that nNOS expression is regulated by the integration of a variety of signals, which all result in the elevation of $\left[\mathrm{Ca}^{2+}\right]_{\mathbf{i}}$. This interpretation is consistent with the diversity of conditions implicated to influence nNOS expression in the nervous system and with what is known about the structure of the 5 -region of the nNOS gene, which contains a number of consensus sequences targeted by several signal transduction pathways, including those activated by changes in $\left[\mathrm{Ca}^{2+}\right]_{\mathrm{i}}$ (Hall et al., 1994). Finally, such an interpretation would also fit a scenario in which NO serves to coordinate neuronal metabolic activity in circumscribed sets of cells (Gally et al., 1990; Pape and Mager, 1992) rather than as a messenger mediating precise point-to-point signaling. Given the complexity of the nNOS promoter region, we expect that additional extracellular signals and intracellular signal transduction mechanisms might be operative in other neuronal systems or other tissues.

Our studies do not address the issue at which level nNOS expression is regulated. Preliminary results indicate that changes in nNOS protein levels are qualitatively paralleled by changes in nNOS mRNA abundance. The complex structure of the nNOS gene and the diversity of mRNA transcripts observed (Ogura et al., 1993; Hall et al., 1994; Ogilvic ct al., 1995; Xic ct al., 1995) suggest that nNOS expression might be regulated on several levels, including transcription, translation, and the assembly of enzymatically functional dimers (Klatt et al., 1995). Presently, we did not observe the occurrence of any molecular weight heterogeneity among immunoreactive nNOS.

A variety of pathological conditions have been shown to induce NOS expression in the nervous system. Likewise, transient expression of NOS during neural development has been reported. In the present investigation, we identified glutamate as a regulator of NOS expression in developing neurons, and we identified both its cellular target and the molecular isoform of NOS involved. These results suggest a scenario in which afferent input during development would regulate the acquisition of the capacity of postsynaptic neurons to synthesize NO. Given the presumed role of NO in synaptic long-term depression (for review and discussion, see Linden and Connor, 1995), this would provide a link between neuronal activity during development and the functional characteristics of adult synaptic systems.

\section{REFERENCES}

Baptista CA, Hatten ME, Blazeski R, Mason CA (1994) Cell-cell interactions influence survival and differentiation of purified Purkinje cells in vitro. Neuron 12:243-260.

Beani L, Tomasini C, Govoni BM, Bianchi C (1994) Fluorimetric determination of electrically evoked increase in intracellular $\mathrm{Ca}^{2+} \mathrm{A}$ in cultured cerebellar granule cells. J Neurosci Methods 51:1-7.

Bredt DS, Snyder SH (1994) Transient nitric oxide synthase neurons in embryonic cerebral cortical plate, sensory ganglia, and olfactory epithelium. Neuron 13:301-313.

Brorson JR, Manzolillo PA, Gibbons SJ, Miller RJ (1995) AMPA receptor desensitization predicts the selective vulnerability of cerebellar Purkinje cells to excitotoxicity. J Neurosci 15:4515-4524.

Chavis P, Nooney JM, Bockaert J, Fagni L, Feltz A, Bossu JL (1995) Facilitatory coupling between a glutamate metabotropic receptor and dihydropyridine-sensitive calcium channels in cultured cerebellar granule cells. J Neurosci 15:135-143.

Clements JD, Lester RAJ, Tong G, Jahr CE, Westbrook GL (1992) The time course of glutamate in the synaptic cleft. Science 258:1498-1501.

Connor JA, Tseng HY, Hockberger PE (1987) Depolarization- and transmitter-induced changes in intracellular $\mathrm{Ca}^{2+}$ of rat cerebellar granule cells in explant cultures. J Neurosci 7:1384-1400.

Courtney MJ, Lambert JJ, Nicholis DG (1990) The interactions between plasma membrane depolarization and glutamate receptor activation in the regulation of cytoplasmic free calcium in cultured cerebellar granule cells. J Neurosci 10:3873-3879.

Davies J, Francis AA, Jones AW, Watkins JC (1981) 2-Amino-5phosphonovalerate (2APV), a potent and selective antagonist of amino acid-induced and synaptic excitation. Neurosci Lett 21:77-81.

Dawson 'IM, Snyder SH (1944) Gases as biological messengers: nitric oxide and carbon monoxide in the brain. J Neurosci 14:5147-5159.

Dawson TM, Bredt DS, Fotuhi M, Hwang PM, Snyder SH (1991) Nitric oxide synthase and neuronal NADPH diaphorase are identical in brain and peripheral tissue. Proc Natl Acad Sci USA 88:7797-7801. 
Farrant M, Feldmeyer D, Takahashi T, Cullcandy SG (1994) NMDAreceptor channel diversity in the developing cerebellum. Nature 368:335-339.

Forti L, Tottene A, Moretti A, Pietrobon D (1994) Three novel types of voltage-dependent calcium channels in rat cerebellar neurons. J Neurosci 14:5243-5256.

Gally JA, Montague PR, Reeke GN, Edelman GM (1990) The NO hypothesis: possible effects of a short-lived, rapidly diffusible signal in the development and function of the nervous system. Proc Natl Acad Sci USA 87:3547-3551.

Gao B, Fritschy JM (1995) Cerebellar granule cells in vitro recapitulate the in vivo pattern of $\mathrm{GABA}_{\mathrm{A}}$-receptor subunit expression. Dev Brain Res 88:1-16.

Gao WQ, Hatten ME (1994) Immortalizing oncogenes subvert the establishment of granule cell identity in developing cerebellum. Development 120:1059-1070.

Garthwaite J, Boulton CL (1995) Nitric oxide signaling in the central nervous system. Annu Rev Physiol 57:683-706.

Garthwaite J, Brodbelt AR (1989) Synaptic activation of $N$-methyl-Daspartate and non- $N$-methyl-D-aspartate receptors in the Mossy fibre pathway in adult and immature rat cerebellar slices. Neuroscience $29: 401-412$

Garthwaite J, Brodbelt AR (1990) Glutamate as the principle mossy fibre transmitter in rat cerebellum: pharmacological evidence. Eur J Neurosc $2: 177-180$

Ghosh A, Greenberg ME (1995) Calcium signaling in neurons: molecular mechanisms and cellular consequences. Science 268:239-247.

Ginty DD, Kornhauser JM, Thomson MA, Bading H, Mayo KE, Takahasi IS, Greenherg IF. (1993) Regulation of CRF.R phosphorylation in the suprachiasmatic nucleus by light and a circadian clock. Science 260:238-241.

Grandes P, Mateos JM, Ruegg D, Kuhn R, Knopfel T (1994) Differential cellular localization of three splice variants of the mGluR1 metabotropic glutamate receptor in rat cerebellum. NeuroReport 5:2249-2252.

Gunluk AE, Bickford ME, Sherman SM (1994) Rearing with monocular lid suture induces abnormal NADPH-diaphorase staining in the lateral geniculate nucleus of cats. J Comp Neurol 350:215-228.

Hall AV, Antoniou H, Wang Y, Cheung AH, Arbus AM, Olson SL, Lu WC, Kau CL, Marsden PA (1994) Structural organization of the human neuronal nitric oxide synthase gene (NOS1). J Biol Chem 269:33082-33090.

Hawkes R, Turner RW (1994) Compartmentation of NADPHdiaphorase activity in the mouse cerebellar cortex. J Comp Neurol 346:499-516.

Ishii T, Moriyoshi K, Sugihara H, Sakurada K, Kadotani H, Yokoi M, Akazawa C, Shigenolo R, Mizuno N, Masu M, Nakanishi S (1993) Molecular characterization of the family of the $N$-methyl-D-aspartate receptor subunits. J Biol Chem 268:2836-2843.

Ito M (1984) The cerebellum and neural control. New York: Raven.

Jahn R, Schiebler W, Ouimet C, Greengard P (1985) A 38,000-dalton membrane protein (p38) present in synaptic vesicles. Proc Natl Acad Sci USA 82:4137-4141.

Ji Z, Aas JE, Laake J, Walberg F, Ottersen OP (1991) An electron microscopic, immunogold analysis of glutamate and glutamine in terminals of rat spinocerebellar fibers. J Comp Neurol 307:296-310.

Klatt P, Heinzel B, John M, Kastner M, Bohme E, Mayer B (1992) $\mathrm{Ca}^{2+} /$ calmodulin-dependent cytochrom $c$ reductase activity of brain nitric oxide synthase. J Biol Chem 267:11374-11378.

Klatt P, Schmidt K, Lehner D, Glatter O, Bachinger HP, Mayer B (1995) Structural analysis of porcine brain nitric oxide synthase reveals a role for tetrahydrobiopterin and L-arginine in the formation of an SDSresistant dimer. EMBO J 14:3687-3695.

Kutsuwada T, Kashiwabuchi N, Mori H, Sakimura K, Kushiya E, Araki K, Meguro H, Masaki H, Kumanishi T, Arakawa M, Mishina M (1992) Molecular diversity of the NMDA receptor channel. Nature 358:36-41.

Lafon-Cazal M, Pietri S, Culcasi M, Bockaert J (1993) NMDAdependent superoxide production and neurotoxicity. Nature 361:535-537.

Laurie DJ, Wisden W, Seeburg PH (1992) The distribution of thirteen $\mathrm{GABA}_{\mathrm{A}}$ receptor subunit mRNAs in the rat brain. III. Embryonic and postnatal development. J Neurosci 12:4151-4172.

Linden DJ, Connor JA (1995) Long-term synaptic depression. Annu Rev Neurosci 18:319-357.

Lowenstein CJ, Snyder SH (1992) Nitric oxide, a novel biologic messenger. Cell 70:705-707.
Matsumoto T, Nakane M, Pollock JS, Kuk JE, Forstermann U (1993) A correlation between soluble brain nitric oxide synthase and NADPHdiaphorase activity is only seen after exposure of the tissue to fixative. Neurosci Lett 155:61-64.

Matute C, Streit P (1986) Monoclonal antibodies demonstrating GABAlike immunoreactivity. Histochemistry 86:147-157.

Meguro H, Mori H, Araki K, Kushiya E, Kutsuwada T, Yamazaki M, Kumanishi T, Arakawa M, Sakimura K, Mishina M (1992) Functional characterization of a heteromeric NMDA receptor channel expressed from cloned cDNAs. Nature 357:70-74.

Meldrum B, Garthwaite J (1990) Excitatory amino acid neurotoxicity and neurodegenerative disease. Trends Pharmacol Sci 11:379-387.

Morgan JI, Curran T (1991) Stimulus-transcription coupling in the nervous system: involvement of the inducible proto-oncogenes fos and jun. Annu Rev Neurosci 14:421-451.

Navone F, Jahn R, Di Gioia G, Stukenbrok H, Greengard P, Decamilli P (1986) Protein p38: an integral membrane protein specific for small vesicles in neurons and neuroendocrine cells. J Cell Biol 103:2511-2527.

Oberdick J, Levinthal F, Levinthal C (1988) A Purkinje cell differentiation marker shows a partial DNA sequence homology to the cellular sis/PDGF2 gene. Neuron 1:367-376.

Ogilvie P, Schilling K, Billingsley ML, Schmidt HHHW (1995) Induction and variants of neuronal nitric oxide synthase type I during synaptogenesis. HASEB J 9:79y-806.

Ogura T, Yokoyama T, Fujisawa H, Kurashima Y, Esumi H (1993) Structural diversity of neuronal nitric oxide synthase messenger RNA in the nervous system. Biochem Biophys Res Commun 193:1014-1022.

Olivera BM, Miljanich GP, Ramachandran J, Adams ME (1994) Calcium channel diversity and neurotransmitter release: the $\omega$-conotoxins and $\omega$-agatoxins. Annu Rev Biochem 63:823-867.

Pape HC, Mager R (1992) Nitric oxide controls oscillatory activity in thalamocortical ncurons. Ncuron 9:441-448.

Pin JP, Duvoisin R (1995) Review: neurotransmitter receptor. I. The metabotropic glutamate receptors: structure and functions. Neuropharmacology 34:1-26.

Pressmar J, Brinkmeier H, Seewald MJ, Naumann T, Rudel R (1994) Intracellular $\mathrm{Ca}^{2+}$ concentrations are not elevated in resting cultured muscle from Duchenne (DMD) patients and in MDX mouse muscle fibres. Pflugers Arch 426:499-505.

Randall A, Tsien RW (1995) Pharmacological dissection of multiple types of $\mathrm{Ca}^{2+}$ channel currents in rat cerebellar granule neurons. $\mathrm{J}$ Neurosci 15:2995-3012.

Schilling K, Barco EB, Rhinehart D, Pilgrim C (1989) Expression of synaptophysin and neuron-specific enolase during neuronal differentiation in vitro: effects of dimethyl sulfoxide. J Neurosci Res 24:347-354.

Schilling K, Dickinson MH, Connor JA, Morgan JI (1991) Electrical activity in cerebellar cultures determines Purkinje cell dendritic growth patterns. Neuron 7:891-902.

Schilling K, Schmidt HHHW, Baader SL (1994) Nitric oxide synthase expression reveals compartments of cerebellar granule cells and suggests a role for mossy fibers in their development. Neuroscience 59:893-903.

Schuman EM, Madison DV (1994) Nitric oxide and synaptic function. Annu Rev Neurosci 17:153-183.

Sheng M, Greenberg ME (1990) The regulation and function of c-fos and other immediate early genes in the nervous system. Neuron $4: 477-485$.

Silver RA, Traynelis SF, Cullcandy SG (1992) Rapid-time-course miniature and evoked excitatory currents at cerebellar synapses in situ. Nature 355:163-166.

Simpson PB, Challiss RAJ, Nahorski SR (1994) Potentiation of $N$-methyl-D-aspartate-evoked elevation of intracellular $\mathrm{Ca}^{2+}$ concentrations by exogenous glycine in cerebellar granule cells. Eur $\mathbf{J}$ Pharmacol Mol Pharmacol Sect 266:309-315.

Somogyi P, Halasy K, Somogyi I, Strom-Mathisen I, Ottersen OP (1986) Quantification of immunogold labeling reveals enrichment of glutamate in Mossy and parallel fibre terminals in cat cerebellum. Neuroscience 19:1045 1050 .

Sorimachi M, Yamagami K, Morita Y, Kuramoto K (1991) GABA inhibits the rise in cytosolic free calcium concentration in depolarized immature cerebellar Purkinje cells. Neurosci Lett 122:229-232.

Sugiyama H, Ito I, Hirono C (1987) A new type of glutamate receptor linked to inositol phospholipid metabolism. Nature 325:531-533.

Tanabe Y, Nomura A, Masu M, Shigemoto R, Mizuno N, Nakanishi S (1993) Signal transduction, pharmacological properties, and expression 
patterns of two rat metabotropic glutamate receptors, mGluR3 and mGluR4. J Neurosci 13:1372-1378.

Wetts R, Phelps PE, Vaughn JE (1995) Transient and continuous expression of NADPH diaphorase in different neuronal populations of developing rat spinal cord. Dev Dyn 202:215-228.

Wheeler DB, Randall A, Tsien RW (1994) Roles of N-type and Q-type $\mathrm{Ca}^{2+}$ channels in supporting hippocampal synaptic transmission. Science 264:107-111.

Williams CV, Nordquist D, McLoon SC (1994) Correlation of nitric oxide synthase expression with changing patterns of axonal projections in the developing visual system. $\mathbf{J}$ Neurosci 14:1746-1755.

Xie JL, Roddy P, Rife TK, Murad F, Young AP (1995) Two closely linked but separable promoters for human neuronal nitric oxide synthase gene transcription. Proc Natl Acad Sci USA 92:1242-1246.

Yu WA (1994) Nitric oxide synthase in motor neurons after axotomy. J Histochem Cytochem 42:451-457.
Yunker AM, Galligan JJ (1994) Extrinsic denervation increases NADPH diaphorase staining in myenteric nerves of guinea pig ileum. Neurosci Lett 167:51-54.

Yuste R, Katz LC (1991) Control of postsynaptic $\mathrm{Ca}^{2+}$ influx in developing neocortex by excitatory and inhibitory neurotransmitters. Neuron $6: 333-344$.

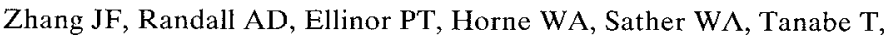
Schwarz TL, Tsien RW (1993) Distinctive pharmacology and kinetics of cloned neuronal $\mathrm{Ca}^{2+}$ channels and their possible counterparts in mammalian CNS neurons. Neuropharmacology 32:1075-1088.

Zhang ZG, Chopp M, Gautam S, Zaloga C, Zhang RL, Schmidt HHHW, Pollock JS, Forstermann U (1994) Upregulation of neuronal nitric oxide synthase and mRNA, and selective sparing of nitric oxide synthase-containing neurons after focal cerebral ischemia in rat. Brain Res 654:85-95. 